\title{
EL REDESCUBRIMIENTO INGLÉS: AMÉRICA CENTRAL SEGÚN LOS DIARIOS PIRATAS
}

\author{
J. Manuel Gómez
}

\begin{abstract}
RESUMO
Este ensaio aborda a quebra epistemológica que se evidencia a partir do século XVII em relação ao saber; em particular, as formas de visualizar e conceber o espaço do saber desde a perspectiva pirata inglesa. Com este propósito, a análise explora os textos resultantes das incursóes pelo istmo da América Central de três corsários de língua inglesa: William Dampier, Lionel Wafer e John Cockburn.
\end{abstract}

PALAVRAS-CHAVE: viagem, saber, corsários.

1 1 saber del espacio americano se manifestó en las cartas de relación tempranas, a través de una visión descriptiva de los nuevos conocimientos que se forjaban dentro del paradigma renacentista del "testigo-narrador"; de aquel que contaba la verdad de su viaje y que marcaba así las postrimerías de un naciente saber científico que se iba a traducir en términos geográficos (geomorfología), con sus imágenes y paisajes humanos (etnografía) para producir un espacio de rendimiento mercantil: "L'œil est au service d'une 'découverte du monde'. C'est la pointe avancée d'une 'curiosité' encyclopédique qui, au XVI siècle, 'entasse frénétiquement' les matériaux et pose ainsi 'les fondements de la science moderne'” 1 . La mirada aparecía como la clave para este tipo de documentación, la cual se relacionaba con el grupo de los saberes teóricos, en la España del siglo XVI, que si bien eran reducidos ya empezaban a contribuir con nociones en diferentes disciplinas: "Las matemáticas,

1 CERTEAU, Michel de. L'écriture de l'histoire. Paris: Gallimard, 1975. p. 242. 
la cosmografía y la astrología eran las únicas cristalizadas como discursos científicos a través de una larga tradición científica" ${ }^{2}$. Por otra parte, el paisaje voluntarista que introdujera Cristóbal Colón en sus cartas también tuvo un peso importante dentro de las descripciones que se dieron del Nuevo Mundo. Algunas de estas descripciones formaban parte del conocimiento europeo, que luego se resignificaron en América.

No obstante el saber espańol de lo americano, celosamente guardado, se enfrentó, a partir del siglo XVII, al paradigma inglés, ávido de aprehender, corroborar o desmitificar tales conocimientos. Este ensayo explora el quiebre epistemológico que se manifiesta a partir del siglo XVII con respecto al saber, en particular: las formas de visualizar y concebir el espacio desde la perspectiva inglesa, la cual entró en competición directa con la visión española que, hasta entonces, había prevalecido. El análisis se centra en los textos de tres corsarios de lengua inglesa y sus correrías por el istmo de América Central: William Dampier ${ }^{3}$ (1689), Lionel Wafer ${ }^{4}$ (1695) y John Cockburn 5 (1735).

En los diarios de viajes de William Dampier, Lionel Wafer y John Cockburn, cuyos recorridos se inician en 1681 y terminan alrededor de 1730 , el sistema de validación documental no era el mismo que inspiraba las tempranas cartas de relación. Aunque aún dotado de un contradictorio halo de veracidad, el nombre del autor no revestía el mismo valor de autoría del que había gozado en la primeras cartas de relación europeas sobre el Nuevo Mundo. Para ese momento, el paradigma había mudado; el dato y el hecho debían ser demostrados de manera sistemática, cuasi científica. El burocrático sistema español de exploración, ocupación y explotación sería utilizado por los ingleses; no obstante, éstos iban a impregnar sus relatos de viajes con su designio imperial, el cual intentaba esclarecer y sistematizar los conocimientos geográ-

2 LÓPEZ-PIÑERO, José María. Ciencia y técnica en la sociedad española de los siglos XVI y XVII. Barcelona: Editorial Labor S.A., 1979. p. 41. Sic.

3 DAMPIER, William. A New Voyage Round the World. Ed.1727. New York: Dover Publications, 1968.

4 WAFER, Lionel. A New Voyage and Description of the Isthmus of America. Cleveland: The Borrows Brothers, 1903.

5 COCKBURN, John. A Journey over Land from the Gulf of Honduras to the Great South Sea. Performed by John Cockburn, and Five Other Englishmen..., To which Is Added, a Curious Piece, Written in the reign of King James I, and Never Before Printed. London: C. Rivington, 1735. 
ficos, etnográficos y naturales; con ello validarían el saber mediante el hecho y el dato fehaciente, sustentados, ambos, con experiencias de primera mano. La descripción a partir de la observación tomó, por lo consiguiente, un matiz imprescindible para el discurso inglés:

A thing of this nature could not but excite us to make the strictest observations concerning it; and accordingly, we stood under the tree near three hours, and found we could not fathom its body in five. We "observed" the soil grew to be very stony ; and upon the nicest "enquiry" both of the natives of the country and Spanish inhabitants, they say there was no other such tree seen throughout New Spain. ${ }^{6}$

El principio fundante del relato de viajes ${ }^{7}$ es hacer un inventario -descripción- de los elementos que componen el espacio, en sus múltiples manifestaciones, y desde allí realizar una arqueología del saber. El viajero, a través de dispositivos ideológicos de visualización, documenta las geografías naturales y humanas representándolas simbólicamente por medio de textualidades o cartografías; es el tipo de narración demostrativa por antonomasia. Esta suerte de escritura se origina en un deseo de conocer; aspecto que involucra los textos imperiales europeos, los coteja, los contrapone, en un intento de corroboración empírica y de sistematización epistemológica. Los españoles elaboran sus relaciones de lo observable y los ingleses las refutan o intentan corroborarlas, haciendo del istmo un continuum de imágenes que se organiza siguiendo el modelo cultural europeo. En otros términos, la geografía natural y humana se visualiza al verbalizarse o cartografiarse según una óptica europeizante, que propone tanto homologías paisajísticas -a la europea- como antinómicas, en caso de extrañeza del medio geográfico, humano o natural.

6 COCKBURN, op. cit., p. 29. Énfasis mío.

7 Se entiende el "relato de viaje" según la acepción que le da Paul Fussel "[Travel narratives] are a subspecies of memoir in which autobiographical narrative arises from the speaker's encounter with distant and unfamiliar data and in which the narrative -unlike a novel or romance- claims literal validity by constant reference to actuality". FUSSEL, Paul. Abroad: British Literature Traveling Between the Wars. New York: Oxford University Press, 1990. p. 203. 
El modelo epistemológico español había propuesto un discurso primero voluntarista $^{8}$. Colón había imaginado Cipango y Catay por lo que buscó representarse el Nuevo Mundo en los términos que lo concebía su propio imaginario. Luego, las tempranas cartas de relación describirían, por ejemplo, la tierra del istmo y lo que en ella había, mediante un modelo programático que establecía una clara analogía con la tierra española o con sus propios mitos? Se puede identificar, en las cartas, un modelo de sistematización a través de la observación y la descripción al mismo tiempo que la comparación y la clasificación ${ }^{10}$. En estos casos las posibilidades de producción a la europea primaban sobre las nativas. La alusión constante, en las relaciones, a "nuestra Espańa" sancionaba las virtudes de la tierra por analogía -legibilidad- ${ }^{11}$ con las de España -Europa finalmente-. La comparación constante entre las geografías conocidas proveía un modelo que explicaba la novedad, era un principio rector que seguían las cartas para no perder de vista su labor: la justificación y legitimación del saber que transcribían, en tanto documento oficial necesario y, en la mayoría de los casos, obligado por la Corona:

The landscape is first aestheticized, then it is invested with a density of meaning intended to convey its material and symbolic richness, and finally it is described so as to subordinate it to the power of the speaker. ${ }^{12}$

No obstante, el relato de viaje inglés, fuertemente ligado al género epistolar, representa el paisaje menos como una homologación y más como una an-

8 “[...] el paraíso terrenal encaramado al pezón famoso de la fantástica teoría colombina". PASTOR, Beatriz. Discurso narrativo de la conquista de América. La Habana: Casa de las Américas, 1983. p. 58.

9 Juan Gil discute, con lujo de detalles, este tema y otras múltiples imágenes del paisaje colombino. GIL, Juan. Mitos y utopias del descubrimiento: I. Colón y su tiempo. Madrid: Alianza, 1989.

10 BUTZER, Karl. "From Columbus to Acosta: Science, Geography, and the New World". Annals of the Association of American Geographers, vol. 83, Issue 3: 543-565, Austin 1992, p. 543.

11 "Legibility, the conversion of diversity into resemblance, thus becomes a powerful model for description and categorization of experience". ORTEGA, Julio. "The Discourse of Abundance." American Literary History, 4: 369-385, Oxford, 1992.

12 PRATT, Mary Louise. Imperial Eyes. Travel Writing and Transculturation. London \& New York: Routledge, 1992. p. 204. 
tinomia -es un paisaje más material que conceptual- que pone al descubierto la diferencia americana, puesto que ni las lenguas europeas ni sus saberes eran capaces de dar una explicación de la diversidad y variedad de lo americano. El método inglés de averiguación y de pesquisa procura la implementación sistemática de un procedimiento empírico, demostrable por repetición, que instaura procesos de deducción y que, de alguna manera, da continuidad al saber español pero desde una óptica de reserva y de duda sobre esa información:

This Gulf ${ }^{13}$ lies near 30 leagues from Panama, towards the S.E. The way thither to Panama is, to pass between the King's Islands and the Main. It is a place where many great Rivers having finished their Courses are swallowed up in the Sea. It is bounded on the $S$ with Point Garachina, which lieth in North lat. 6 d. 40 m. and on the North-side with Cape St. Lorenzo. Where by the way, "I must correct an Error in our common Maps". ${ }^{14}$

La descripción inglesa se transforma en un saber que vehicula otro tipo de informaciones referentes a lo que se podría designar como la geografía, la historia natural y la etnografía de América Central. Mediante el espionaje sistematizado y debidamente rubricado por la Corona inglesa, Dampier, Wafer y Cockburn tanto exploran y cartografían -espían- como sientan las bases de un conocimiento que escapa a la órbita española para erigirse en un "saber alterno", un saber paralelo y en otro idioma sobre una misma región.

La geografía que reconocen Dampier, Wafer y Cockburn está vinculada estrechamente con puntos codiciados por los ingleses. Dicho territorio se extiende bastante hacia el norte desde Belice hasta el golfo de Urabá, entre Panamá y Colombia, en el litoral Caribe y desde San Miguel, El Salvador, hasta el Darién en Panamá sobre el litoral Pacífico. Dampier comienza a describir su recorrido costero del litoral Pacífico, antes de poner pie en tierra firme, en el istmo de Darién. En abril de 1681, entra por la boca del río Congo y hunde su barco ante la inminente persecución de los espańoles, ya avisados de su presencia en la zona:

13 Se trata del golfo de San Miguel, en Panamá, que Dampier referencia como "St. Michael". DAMPIER, op. cit., p. 137.

14 Ibidem, p. 137. Énfasis mío. 
I persuaded them to run into River Congo ${ }^{15}$... When we had rowed and towed against the Wind all Night, we just got about Cape St. Lorenzo, in the Morning; and sailed about 4 Miles farther to the Westward, and run into a small Creek within two Keys, or little Islands, and rowed up to the Head of the Creek, being about a Mile up, and there we landed, May 1 . $1681 \ldots$ We got out all our Provision and Cloaths, and then sunk the Vessel. ${ }^{16}$

Procede luego a cruzar transversalmente el istmo de Panamá, con lo cual toca muchos otros puntos. Enseguida se ve forzado a hacer un recorrido por toda la costa caribe y luego la pacífica en diferentes momentos.

Lionel Wafer formaba parte de la misma expedición pirata que Dampier. Luego de un accidente queda atrás, abandonado entre los pueblos Cuna de Darién Panamá; el mismo corrobora el espacio al cotejar el texto de Dampier:

He [Dampier] hath given also an Account of what befel us in that Return, till such time as by the Carlesness of our Company, my Knee was so scorch'd with Gunpowder, that after a few Days further March, I was left behind among the Wild-Indians in the Isthmus of Darien. ${ }^{17}$

Por su parte, John Cockburn anota en su bitácora de viaje que zarpa a bordo del John \& Jane ${ }^{18}$ con destino a Jamaica, el 18 de enero de 1730 . Vuelven a izar vela el 19 de marzo hacia el sur y son abordados por un barco inglés - the Two Brothers ${ }^{19}$ - con bandera española. Son finalmente abandonados a su suerte en una isla frente a la costa de la actual Honduras, en una fecha posterior no identificada: "Their Orders ran to carry us to a little desolate Island at some Distance off, where putting us on Shore, they left" ${ }^{20}$. En este punto

\footnotetext{
15 Panamá. Sic.

16 DAMPIER, op. cit., p. 14-15.

17 Ibidem, p. 33.

18 COCKBURN, op. cit., p. 1.

19 Ibidem, p. 2.

20 Ibidem, p. 9.
} 
se inicia el recorrido por el istmo hasta finalizar en Porto Bello, Panamá: "At the End of four Weeks after we received an Answer, the Snows arrived, and then we were demanded as Subjects of England, and straitways released, and sent on Board"21. La nave había anclado en Porto Bello y los esperaba para repatriarlos a Inglaterra vía Jamaica.

En virtud de su recorrido geográfico, este análisis se circunscribe a los relatos de viaje, $A$ Voyage Round the World de William Dampier -publicado por primera vez en 1697-, A New Voyage and Description of the Isthmus of America by Lionel Wafer-publicado en 1699- y A Journey over Land from the Gulf of Honduras to the Great South Sea. Performed by John Cockburn, and Five Other Englishmen..., To which Is Added, a Curious Piece, Written in the Reign of King James I, and Never Before Printed, de John Cockburn - publicado por vez primera en 1735. Los textos que se utilizan obedecen, por ende, a una necesidad de establecer un punto de origen, de llegada y de exploración. La región ístmica de América resulta ser para estos bucaneros, espías y aventureros un común denominador. Separados por tres décadas, estos diarios de viaje reestructuran la geografía americana desde una perspectiva no española y en lengua inglesa. Estas relaciones de viaje establecen, por lo consecuente, nexos, contigüidades y a veces desencuentros o rupturas de orden epistemológico, pero sobre todo hacen patente la reconstrucción de un espacio mediante recorridos que cartografían, describen e inscriben nuevos espacios y sujetos en los imaginarios y el saber tanto europeos como americanos.

Inglaterra llegó un poco tarde a la exploración del Nuevo Mundo. Tras el desastre de la Armada española en 1588, Inglaterra se lanza a la aventura de su rival -España, la que ya estaba bien afincada en América habiendo establecido, también, un sistema de explotación de recursos americanos que se exportaban a Europa. De este modo, Inglaterra busca la manera de encontrar sus propios recursos en tierra americana. A falta de un flujo de metales preciosos en la isla -oro principalmente-, Inglaterra vuelve su mirada hacia el Nuevo Mundo en busca de fortuna:

Like the rise of interior exploration, the systematic surface mapping of the globe correlates with an expanding search for

${ }^{21}$ Ibidem, p. 264. 
commercially exploitable resources, markets, and lands to colonize, just as navigational mapping is linked with the search for trade routes. ${ }^{22}$

Durante el siglo XVII, sobre todo en la segunda mitad, corsarios y piratas, bajo la protección del Imperio inglés, surcan las aguas del Caribe, atacan barcos, fuertes y ciudades españoles, capturan ingentes cantidades de oro para, finalmente, hacerse con la Isla de Jamaica en 1655 y establecer colonias en otros puntos del Caribe y Norteamérica -la colonia de Jamestown, por ejemplo.

Por otra parte, se habían creado en Inglaterra diversas compañías para agilizar el comercio entre la India y sus recién conquistados bastiones en el Caribe, ejemplos de ellas: The East Indian Trading Company (1600), The Hudson Bay Company (1670), The Royal Africa Company (1672) -muy controvertida por su tráfico de esclavos. Si bien ni los viajes de exploración ni los nuevos asentamientos suplieron los tan anhelados metales, sí establecieron un flujo de otros productos - pieles y especias entre otros- y, sobre todo, una geografía por redescubrir y por qué no: reconquistar.

\section{Autor, autoridad y saber}

A través de la exégesis textual se produce una reinscripción espacial de la frontera ${ }^{23}$ ístmica quedando representada en otro discurso imperial -el inglés. El proyecto baconiano que buscaba sistematizar el saber, bajo formas demostrables, se unifica en los textos ingleses, cuyos discursos tienden, al igual que los proyectos cartográficos, a unir una realidad múltiple, con el fin de propiciar una idea de uniformidad, de completitud o por lo menos la ilusión de control sobre el espacio. Este control se establece a partir del conocimiento físico de los lugares que constituyen ese espacio, conjuntamente con las geografías humanas. Según Anna Neill:

22 PRATT, op. cit., p. 30.

23 El término frontera adquiere aquí el mismo sentido que zona de contacto: "[C]ontact zone is an attempt to invoke the spatial and temporal copresence of subjects previously separated by geographic and historical disjunctures, and whose trajectories now intersect". PRATT, op. cit., p. 7. 
At the same time, the often detailed natural and human histories included in the buccaneer journals ${ }^{24}$ appealed to those in scientific and official circles who saw that, along with the opportunities for raw products and new markets, they offered significant contributions to the national geographical archive. ${ }^{25}$

Por ende, el aspecto científico se vuelve muy palpable en cuanto al discurso inglés, cuyo interés se suscitó más tempranamente que en otras latitudes europeas. Se está en presencia de un momento histórico, en el cual Inglaterra ostenta una posición envidiable en relación con Europa, puesto que intentaba sistematizar el conocimiento mediante una aproximación científico-empírica.

John Cockburn relata su encuentro con un curioso árbol de cuyas hojas mana agua, en un momento crucial en que él y sus compañeros de travesía sienten que mueren de sed; este acontecimiento ocurre durante abril o principios de mayo, estación de sequía en el istmo; su experiencia acontece en un lugar que él llama Verapaz y que se encuentra en el Departamento de Santa Bárbara, en Honduras:

We had perceived, at some Distance off, the Ground about it to be wet, at which we began to be somewhat surprized, as well knowing there had no Rain fallen for near six Months past, according to the certain Course of the Season in that Latitude; and that it was impossible to be occasioned by the Fall of Dew on the Tree ... At last, to our great Amazement, as well as Joy, we saw Water dropping, or as it were distilling fast from the End of every Leaf of this wonderful (nor had it been amiss if I had said miraculous) Tree. I do not represent this as a Prodigy in Nature, because I am not a "Philosopher enough" to ascribe any natural cause for it; the "Learned" may, perhaps, give

24 "The Buccaneer Journals" son narrativas de viaje, que se inician con Francis Drake en 1570 y finalizan más o menos por allí de 1740. Estas narrativas recuentan las aventuras e infortunios de filibusteros que se dedicaban a la caza y toma de buques españoles tanto en aguas del Caribe como del Mar del Sur (el Pacífico).

25 NEILL, Anna. "Buccaneer Ethnography: Nature, Culture, and Nation in the Journals of William Dampier”. Eighteenth-Century Studies 33: 165-180. Baltimore, 1999-2000. 
substantial Reasons in Nature, for appeared to us as a great and marvelous Secret. ${ }^{26}$

Frente a un hecho inusitado en el corazón del istmo de América, John Cockburn manifiesta: "I am not Philosopher enough"; no logra explicarse tal prodigio. Asimismo, William Dampier en la Introducción a su libro le comenta a Charles Montague, presidente de la Royal Society ${ }^{27}$ :

Yet dare I avow, according to my narrow sphere and poor abilities, a hearty Zeal for the promoting of useful knowledge, and of any thing that may never so remotely tend to my Countries advantage. And I must own an Ambition of transmitting to the Publick through your hands, theses Essays I have made toward those great ends, of which you are deservedly esteemed the Patron. ${ }^{28}$

De otra parte Wafer, en su Prólogo, transmite la importancia de la observación al escribir sobre la novedad y las rarezas que presenció como testigo de primera mano en el istmo del Darién:

My principal Design was to give what Description I could of the Isthmus of Darien, where I was left among the wild Indians: And as for the preceding and subsequent Relations, I have, in them, only briefly represented the Course of my Voyages; without particularizing, any further, than to speak of a few Things I thought more especially remarkable. I cannot pretend to so great an Exactness, but that I may have fail'd in some Circumstances, especially in the Descriptional Part; which I leave to be made up by the longer Experience, and more accurate Observations of Others. But I have been as careful as I could: And tho there are some Matters of Fact that will seem strange, yet I have been

26 COCKBURN, op cit., p 43. Énfasis mío.

27 Institución fundada en 1660 bajo la corona de Carlos II de Inglaterra, cuyo cometido fue y ha sido fomentar la discusión y la investigación. 
more especially careful in these, to say nothing but what, according to the best of my Knowledge, is the very Truth. ${ }^{29}$

Wafer apostrofa al lector, con el cual se disculpa, en caso de que sus datos resulten ser inexactos; no obstante, según él, este saber es "verdadero".

La cita de Cockburn llama la atención sobre un hecho maravilloso que ha observado. Su comentario se enlaza con la curiosidad y la continuidad del saber de la geografía y la naturaleza del istmo. Cockburn al no saber -no es filósofolo deja al entendido en materia de ciencia, a quien él refiere como "the learned" (el sabio/el letrado). Dampier reconoce sus limitaciones, "poor habilities", pero redunda en el hecho de la expansión y el avance del saber promoviendo el conocimiento útil; por otro lado, llama la atención acerca de la necesidad de constituir un conocimiento de esta región. Wafer afirma que le deja la tarea investigativa de tales fenómenos a los observadores con más experiencia. Los tres comentarios coinciden en un lugar común: el procedimiento empírico, puesto que se encuadran dentro de la ruptura epistemológica que se ha venido gestando en Europa, como parte de las técnicas que producen el saber; procedimientos que se inician a partir de lo observable, de lo repetible, de lo sistematizable.

La publicación en 1605 de la obra de Francis Bacon marca un momento crucial en la historia occidental. Esta obra, titulada The Advancement of Learning, publicada en Londres en 1605, proponía una triple dialéctica para dinamizar, sistematizar y librar de lastres el método para producir el conocimiento. Esta tripartición consistía en la consideración del espacio, del tiempo y del ente social que reflejarían sino el nacimiento al menos una ruptura con los modelos de conocimiento anteriores, engendrando así el saber moderno. Mediante la unión de la filosofía racional y la experimental, Bacon proponía el abandono de los métodos escolásticos, normalmente religiosos, que propendían a lecturas aristotélicas de los fenómenos naturales. Bacon planteaba alcanzar el conocimiento a partir de la observación y de la rutina mecánica con la cual se eliminaba la inducción, método que había dado al traste con el progreso científico. De esta manera, se aseguraba un avance gradual desde lo particular hacia lo general. Es decir que al observar un fenómeno se podría establecer una teoría general del fenómeno observado.

29 WAFER, op. cit., p. 31. 
Además, para llegar a producir tal o cual teoría había que constreñirse a un grupo de reglas que circunscribían la producción del conocimiento natural. Esta Nueva Ciencia, según Bacon, tenía que obedecer a lo siguiente: "We must march by line and level, all the way, even from the fisrt perception of senses ... by a certain rule, and constant method of proceeding". Bacon acudía al empirismo ${ }^{30}$ como forma demostrativa para avanzar en el conocimiento. Tres aspectos capitales se subsumen en su obra, los que marcaron la sociedad inglesa de su tiempo: experiencia, observación y sentido común. Otro aspecto capital que toca Bacon tiene que ver con el uso del lenguaje, el cual tenía que abstenerse de excesos de elocuencia y mucho menos detenerse a citar "antiquities and citations or testimonies of authors ... everything in short that is philological" ${ }^{1}$. Es decir, el lenguaje debía producir el saber libre de retórica superflua que oscureciera su significado.

Las descripciones de William Dampier en New Voyage Round the World se adscriben plenamente a ese deseo de dejar lo superfluo por fuera y concentrarse en la claridad del significado, es decir, en el asunto. Según Hasty ${ }^{32}$, uno de los significados de la narrativa de Dampier residía en establecer su credibilidad científica, su veracidad y su autoridad. Las notas del bucanero adquieren gran notoriedad por su exactitud sin disquisición alguna:

We reckon the Periagoes and Canoas are made of Cedar to be the best of any; they are nothing but the Tree it self made hollow Boatwise, with a flat bottom, and the Canoa generally sharp at both ends, the Periago at one only, with the other end flat. But what is commonly said of Cedar, that the Worm will not touch it, is a mistake, for I have seen of it very much Worm-eaten. ${ }^{33}$

30 Según Myers el empirismo se define como el conocimiento que proviene de la experience de los sentidos y de la ciencia que florece a partir de la observación y la experimentación. MYERS, D. Psychology (7 $7^{\text {th }}$ ed.). Michigan: Hope College, 2004.

31 BAUER, Ralph. The Cultural Geography of Colonial American Literatures. Empire, Travel Modernity. Cambridge: Cambridge University Press, 2003. p. 14.

32 WILLIAM HASTY. "Piracy and the production of knowledge in the travels of William Dampier, c.1679 -1688". Journal of Historical Geography, 37: 40-54, Toronto, 2011. p. 42. 
Wafer, por su parte, en $A$ New Voyage and Description pondera, con profunda curiosidad y no menos sorpresa, los emplastos practicados por los cuna, en su herida, y que la sanaron en cuestión de días.

Being now forc'd to stay among them, and having no Means to alleviate the Anguish of my Wound, the Indians undertook to cure me; and apply'd to my Knee some Herbs, which they first chew'd in their Mouths to the Consistency of a Paste, and putting it on a Plantain-Leaf, laid it upon the Sore. This prov'd so effectual, that in about 20 Days Use of this Poultess, which they applied fresh every Day, I was perfectly cured; except only a Weakness in that Knee, which remain'd long after, and a Benummedness which I sometimes find in it to this Day. ${ }^{34}$

De esta manera, Wafer no sólo describe el espacio del istmo del Darién, sino que anota una serie de observaciones que evalúa con un gran apego científico. Se concluye lo mismo al revisar otra de sus notas, que observa y describe la forma de obtener la sal:

Salt, they have it out of the Sea-water; which they boil up and evaporate in Earthen Pots, till the Salt is left in a Cake at the bottom, which they take out and break in pieces for use: But as this is a tedious way, so they have but little, and are very choice and sparing of it. ${ }^{35}$

Por lo tanto, la triple dialéctica propuesta por Bacon se puede sentir en toda su magnitud. Las voces "philosopher" y "learned" introducen las claves para la interpretación del relato de viajeros y sus vinculaciones con el saber aunque, como afirma Cockburn, él no sea un filósofo, es decir un hombre de ciencia. De forma análoga, el relato de William Dampier no solamente llama la atención sobre la técnica que se utiliza para fabricar las canoas y las piraguas sino que también insiste en diferenciar ambos tipos de embarcación ligera.

34 WAFER, op. cit., p. 88.

35 WAFER, op. cit., p. 139. 
Wafer, aunque incrédulo, a veces, no hace sino manifestar su curiosidad ante los hechos, los observa, saca conclusiones y los anota.

Sin embargo, las descriptivas imágenes sobre fenómenos y observaciones son sólo un aspecto del proceso; el factor de más peso en las anotaciones viene del procedimiento empírico del cual se sirve Dampier, por ejemplo, para hacer su demostración. Primero, observa "I have seen"; luego manifiesta un juicio a partir de la comparación del mismo fenómeno en muchas otras piraguas y canoas "very much Worm-eaten", hechas de cedro que, según la creencia popular, "the Worm will not touch it". Realizando una generalización, Dampier, pone en relieve el error "is a mistake" y estipula, al mismo tiempo una regla donde prima una imagen que tiene que ver con la verdad de la observación. Es decir, va del caso particular hacia la generalización, procedimiento que Bacon había instaurado como procedimiento científico ideal.

Para 1660, la Royal Society of London había adoptado y proclamado el sistema baconiano como su política en cuanto al lenguaje para promover el avance científico. Con ello querían resarcirse de los excesos y disquisiciones que habían marcado el pasado de la filosofía natural ${ }^{36}$. Los aspectos especulativos y operativos de la Nueva Ciencia se debían entender y tratar por separado. Los aspectos operativos tenían que ver con los procedimientos de observación -la empiria de lo sensorio-, es decir el espectador que escudriña como en el caso de los bucaneros, quienes observan primero. Luego, el aspecto especulativo estaba llamado a realizar juicios o formular verdaderos axiomas.

Herederas de Francis Bacon, estas relaciones de viaje establecen un lazo estrecho y directo con el sistema político-científico inglés de aquel momento. Desde la perspectiva política, la retórica baconiana reformula el expreso deseo de centralizar la monarquía, ante el empuje de las clases comerciantes que significaban un peligro para el anquilosado reclamo real que pretendía poder y saber absolutos. En todo caso, se ha afirmado que los planteamientos de Bacon significaron un avance importante: "in making the production, ownership, and organization of knowledge the 'department of the state" "37. No obstante, más allá de los aspectos relativos a la política interna o externa, el avance científico manifestaba el designio del discurso imperial que tendía a

36 BAUER, op. cit., p. 14.

37 Ibidem, p. 16. 
concentrar el conocimiento: "[I]n the building of a cohesive national infrastructure supporting an overseas empire that would allow England to compete in geopolitical contest against her European Neighbors" 38 , como parte de su discurso expansionista pero, sobre todo, mercantilista.

Así, el discurso imperial inglés aparece como una yuxtaposición, dentro de la urdimbre de poderes ya en pugna en América y en particular en una zona de circunnavegación, de comercio intérlope y de piratería tan activa como lo era la cuenca del Caribe. Los relatos de viajes de Dampier, Wafer y Cockburn, encabalgados entre las décadas finiseculares del siglo XVII y las postrimerías del XVIII, van a marcar, a la vez, una continuidad y una ruptura en la búsqueda del conocimiento, puesto que el sistema de pesquisa va a exigir pruebas fehacientes al igual que un método confiable. Los espacios geográficos con sus habitantes, que habían sido descritos por los exploradores españoles, quedan mejor delineados por los ingleses, quienes recorren largos trayectos en busca del dato exacto: "The Lake of Nicaragua vents itself into the North-Sea, and tho' it be very shallow, is about fifteen Leagues broad in the widest Part, but near the Castle it is not above a Mile over, as Barnwell ${ }^{39}$ informed us" ${ }^{40}$. Mensuran las regiones y cartografían los espacios desmitificando, coligiendo o desmintiendo el conocimiento previo de origen normalmente español: "Could we have gone up Cheapo River, or Santa Maria River; for at either of those Places a Man may pass from Sea to Sea in three Days time with ease" ${ }^{41}$. De paso, describen el potencial de la región: "As this Country is very Woody, so it contains great variety of Trees, of several Kinds unknown to us in Europe, as well Fruit-Trees as others" 42 y de los grupos humanos -los Cuna:

The size of the Men is usually about 5 or 6 Foot. They are streight and clean-limb'd, big'd-bon'd, full-breasted, and handsomly shap'd. I never saw among them a crooked or deformed Person.

38 Ibidem, p. 17.

39 Se trata de un inglés cuyo nombre es Robert Barnwell, nacido en West-Chester y que había vagado por cerca de cinco ańos en la región sin poder abandonarla. Cockburn se encuentra con él en las inmediaciones de Granada, Nicaragua. COCKBURN, op. cit., p. 127.

40 Ibidem, p. 127.

41 DAMPIER, op. cit., p. 25

42 WAFER, op. cit., p. 84. 
They are very nimble and active, running very well. But the Women are short and thick, and not so lively as the Men. The young Women are very plump and fat, well-fhap'd; and have a brisk Eye. ${ }^{43}$

No cabe duda de que el relato de Wafer sobresale por sus descripciones puntillosas sobre el istmo como "a precious document of ethnohistory" ${ }^{4}$. Es decir, se establece en el istmo una guerra de discursos; los cuales pusieron en movimiento un enfrentamiento de poderes que se articulaban en el campo político, económico, así como en la creación, la manipulación y el dominio del saber.

Ante el hermetismo español, la respuesta de otros imperios se tradujo en el recorrido a hurtadillas de los espacios españoles. Estas geografías, apenas figuradas, se convierten en el foco de acción del discurso inglés, como contra-respuesta a la exploración y expansión de los dominios de la Corona española. Los relatos de viajes de William Dampier, Lionel Wafer y John Cockburn ejemplifican el designio de extender el dominio según la premisa del conocimiento empírico, bajo los auspicios de los postulados científicos baconianos, los cuales ambicionaban:

[...] study nature rather than books, and from the observations, made of the phenomena and Effects she presents, to compose such a History of Her, as may hereafter serve to build a solid and useful Philosophy upon [...] to keep an exact diary, delivering at their return a fair copy thereof to the Lord High Admiral of England, his Royal Highness the Duke of York, and another to the Trinity-house, to be perused by the R. Society. ${ }^{45}$

El istmo central de América deviene, entonces, un laboratorio donde se ponen a prueba las teorías de Bacon y, al mismo tiempo, se mide la verdad

43 Ibidem, p. 131.

44 SPATE, O. H. K. The Pacific since Magellan II: Monopolists and Freebooters. Minneapolis: University of Minnesota Press, 1983. p. 157.

45 ROYAL SOCIETY, Directions for sea-men bound for far voyages, Philosophical Transactions of the Royal Society, 143-144, London: 1651-1678. 
del conocimiento tanto español como inglés. Los relatos de viajes se transforman, por lo tanto, en instrumentos que enmarcan una disputa ya no sólo geográfica sino también que se convierten en un instrumento que sienta las bases del conocimiento científico moderno, donde el saber se articula en términos de un accionar político que controla su circulación, su recepción e inclusive su práctica.

\section{E1 istmo: del concepto a su materialización}

Los relatos de viajes ponen en contacto diferentes puntos nodales que constituyen el espacio: "the journey and the writing about it are inseparable projects -they presuppose each other and create each other's significance" 46 . Es decir, la referencialidad de los jalones espaciales llena y reclama la geografía entre ellos. Tal espacio se traduce mediante formas y conceptos, los que de una u otra manera se venían repitiendo dentro del nuevo paradigma de la cartografía, así como otros que eran más o menos nuevos: distancias, descriptores geográficos como topónimos y geografías reales o míticas. Estas tácticas surgen de la relación y la bitácora a través de la descripción y la medición científica. Afirma Michel de Certeau que dicho procedimiento es un acto que va más allá de la simple fijación. En el mismo tenor, Lotman corrobora esta idea al afirmar que la descripción es "un acte culturellement créateur" ${ }^{37}$. En otros términos, los detalles geográficos sobre los que abunda el relato de viajes son prácticas del espacio, tanto discursivas como físicas que construyen imágenes mentales en la ausencia del objeto puesto que lo describen constantemente.

Esta práctica discursiva del espacio se manifiesta, en los relatos de Dampier, Wafer y Cockburn, bajo un común denominador; es una invasión física y a la vez discursiva que aumenta el conocimiento inglés sobre el istmo, creando un registro económico, geográfico y social de buena parte de América Central, dentro del discurso histórico de la rivalidad hispano-inglesa. Los relatos adquieren, por lo tanto, un carácter de dispositivos que revelan las relaciones del espacio, a la vez que articulan el poder imperial, en sus facetas primordiales para la región; es decir que se está en presencia de la invasión territorial, físi-

46 PRATT, op. cit., p. 201.

47 LOTMAN, Yury M. Travaux sur les systèmes de signes. Bruxelles: Éditions Complexe, 1976. p. 89. 
camente hablando, y luego mediante el discurso se crea un registro histórico que invade la historia mesoamericana y la europea, en un espacio de zona de contacto. Estos desencuentros europeos imprimen imágenes que engendran una conflictiva relación dentro de la geopolítica de la cuenca del Caribe.

El saber en las tempranas cartas de relación se había creado mediante descripciones que, a su vez, consistían en mostrar un paisaje a la vez europeo pero diferente. Dicho conocimiento se desarrolló, en un primer momento, en virtud de la necesidad de crear un nuevo paradigma que explicase la diferencia espacial en términos de relaciones del sujeto americano y, por supuesto, del sujeto europeo, de cara a una realidad completamente diferente y mucho más diversa que cualquier cosa conocida para el viajero/explorador. En contraposición, la descriptiva imaginería que va a utilizar el inglés se va a constituir a partir de un hondo sentido de pragmatismo. Las técnicas descriptivas se manifiestan como un discurso que produce un conocimiento primigenio acerca de las novedades y curiosidades del Nuevo Mundo, a lo que se ha dado en llamar "'historia natural' in terms of territorialized economies of knowledge production, 'empires of truth' that were structured by a geo-political order that might be characterized by forms of epistemic mercantilism" ${ }^{48}$. Dicho de otro modo, el espacio se torna objeto de estudio en sus dimensiones económicas y políticas.

Se hizo pues necesaria la invención de un nuevo paradigma que diera cuenta de las posibilidades mercantiles del nuevo espacio. Ya no tanto en términos del sujeto y su relación con su imaginario cultural, sino más bien en términos de las posibilidades de explotación y colonización. La visión inglesa del espacio y sus figuraciones denota un espacio para usufructuar y como tal se le describe y se le trata de imaginar. El espacio no es más una simple imagen que se concibe en términos estéticos, mitológicos o incluso voluntaristas, sino un uso de la geografía capaz de rendir materialmente.

Los relatos de viajeros contienen la médula, de acuerdo con la afirmación de Bauer, de toda la información concerniente a los bienes y probables explotaciones que planteaba la voracidad mercantil imperial, que desde luego no era sólo inglesa: "The poetics of this mercantilist production of knowledge demanded a division between imperial peripheries and centers, the effacement

48 BAUER, op. cit., p. 4. 
of colonial subjects, and the transparency of colonial texts as providers of raw facts" ${ }^{29}$. En otros términos, se asienta una ideología sobre la zona de contacto ístmica en términos de prácticas y usos, lo cual se relaciona estrechamente con el saber colonial. Al mismo tiempo, los relatos de viajes se transforman en vehículos de información esencial que instrumentalizaban los discursos invasores, dado que proporcionan datos sobre las materias primas, desde la periferia hacia los centros de poder.

Desde la atalaya de este saber, se constituye un espacio objeto al que se analiza en sus posibilidades de beneficio. Dampier relata, por ejemplo, su encuentro con el capitán Wright y un grupo de piratas, en el que se lleva a cabo un cuestionario exhaustivo, una especie de reconocimiento militar, económico:

For they make their Business to examine all Prisoners that fall into their Hands, concerning the Country, Town, or City that they belong to; whether born there, or how long they have known it? how many families, whether most Spaniards? or whether the major part are not Copper-colour'd, as Mulattoes, Mustesoes, or Indians? whether rich, and what do their Riches do consist in? and what their chiefest Manufactures? if fortified, how many great Guns, and what Number of small Arms? whether possible to come undescrib'd on them? How many Look-outs or Centinels; for such the Spaniards always keep? and how the Look-outs are placed? Whether possible to avoid the Look-outs, or take them? If any River or Creek comes near it, or where the best Landing; with innumerable other such Questions, which their "Curiosities" ${ }^{50}$ led them to demand. ${ }^{51}$

Esta "curiosidad" evidencia la visión inglesa desde más de una arista. La primera tiene que ver con un sujeto en principio no representativo de lo inglés -se trata de un pirata- que lleva a cabo un interrogatorio buscando

\footnotetext{
49 Ibidem, p. 4.

50 Énfasis mío.

51 DAMPIER, op. cit., p. 28.
} 
informaciones de primera mano. Siendo el pirata un sujeto fuera de la ley y por eso fuera de control, el cuestionario muestra la manera en que el proceso del saber ha permeado el discurso inglés: hasta sus súbditos más subalternos -el bucanero es un ente marginal, que no necesariamente se adhería a la legalidad-sancionan el discurso mediante un cuestionamiento práctico, siguiendo así la lección baconiana.

Las bitácoras de viaje inglesas se inclinan consecuentemente hacia la cientificidad. Existe innegablemente un deseo de plasmar sobre papel cualquier curiosidad o dato que pudiera representar algún provecho ulterior, con lo que el paisaje se convierte en depositario de las posibilidades económicas disponibles y aprovechables:

This Town of Candiliero is pleasantly situated, being surrounded with fine Coco Nut and Plantain Trees, which are beautiful to the Eye; the Fruit of which are what the Inhabitants chiefly live on. Plantains are always seen on level Ground, growing in Thickets or rather Groves, but are commonly called by the Natives Plantains Walks; their Bodies are of a clear green, and smooth as Glass, being very strait, and about twenty Foot high. The fruit grows as the Top, and is covered with great Leaves, which are eight or ten Foot long, and four Foot Broad, and are also very useful to the Indians. The Trunk is about Three Foot in Circumference, but so tender that a Man cut it down with a Stroke of a Knife [...] and after the Tree is cut down in this Manner, another will arise from the same Root, and in a twelve Month's Time comes to full Perfection, bearing Fruit as the former. ${ }^{52}$

La concreción de la técnica descriptiva regula constantemente la imagen de lo americano, la cual se evidencia mediante una heterotopía; esta última subsume la intención al discernir el paisaje conceptual en su legibilidad -asimilación comparativa- o en sus antinomias -contraste-, lo que preconiza, al mismo tiempo, un cambio estratégico en la forma de mirar el paisaje en su

52 COCKBURN, op. cit., p. 23-24. 
materialidad. La iconografía del paisaje, en sus diversas posibilidades, ya no es sólo humana sino explotable y, desde luego, lucrativa. Este aspecto determina el vital desencuentro discursivo inglés con el español y sus repercusiones en el istmo y en el saber acerca de éste.

Las tempranas técnicas del saber, las cuales fueron denominadas históricamente como Discourse of Language en la Inglaterra de los siglos XVI y XVII ya hablaban de un cambio hacia la observación en vez de hacia la lectura: "Look rather than read, verify rather than comment". Los relatos de Dampier, Wafer y Cockburn están imbuidos en ese ideal científico que se había venido gestando bajo los auspicios de los Estuardo y que culmina con la institucionalización, en 1662, del avance del saber, para promover la filosofía experimental y que se convertirá en la "Royal Society": "Now English imperial spirit was formally linked to state investment in scientific discovery and the improvement of natural knowledge" 53 .

El Discourse of Language propicia un conocimiento científico, del cual deviene también mecenas, que tendía a hacerse con el control del saber con el fin específico de accionar el poder imperial. Los aventureros ingleses van a surcar las aguas de la América Central con el cometido de corroborar o desmentir las informaciones españolas relativas a los descubrimientos de las tierras americanas, en un afán de disputar a otras potencias europeas Holanda y Francia entre otras- parte del botín americano. Las narraciones de estos bucaneros propician el entendimiento de una posición geográfica ideal para vigilar la administración y el comercio español, permitiendo inventariar los recursos naturales y humanos, cuya información se guardaba celosamente o era escueta o simplemente inexistente; además, el espacio del Caribe de la América Central estaba prácticamente desprovisto de fuertes españoles, por lo cual fue caldo de cultivo para las empresas bucaneras. El saber recopilado por los bucaneros puso en marcha, por lo tanto, el poder inglés en la zona ístmica, determinando desde más de una vertiente otro saber sobre la geografía, la historia y las etnicidades de la entonces y actual América Central.

53 NEIL, op. cit., p. 167. 


\title{
THE ENGLISH RE-DISCOVERY: CENTRAL AMERICA ACCORDING TO PRIVATEER TRAVEL LOGS
}

\begin{abstract}
This paper examines the epistemological shift that took place in England during the 17th Century and how it was reflected in piratical and buccaneer travel logs. It explores the practices of visualization and space in quest of knowledge, in the narrative of three privateers who crisscrossed the Central American isthmus: William Dampier, Lionel Wafer, and John Cockburn.
\end{abstract}

KEYWORDS: travel, knowledge, privateers.

Recebido em: 16/03/12

Aprovado em: 25/11/12 